\title{
The biomass potential of some selected native and non-native species for afforestation - a case study from western Norway
}

\begin{abstract}
The potential of increased biomass production and raised carbon sequestration in forest to mitigate climate change has actualized tree species choice. Biomass production in mature plantations of eighteen non-native tree species located on the west coast of Norway were compared with neighbor stands of seven native tree species in three research areas. Validated biomass functions were available for the native species Norway spruce, Scots pine and Downy birch, for the other selected species we applied specific wood gravity records from Norwegian stands combined with biomass expansion factors to estimate aboveground dry matter production. In stands of Sitka spruce in western Norway, local yield class of $24 \mathrm{~m}^{3} \mathrm{ha}^{-1} \mathrm{yr}^{-1}$ age 80years and a mean aboveground biomass production of 10.6 tons $\mathrm{ha}^{-1} \mathrm{yr}^{-1}$ were recorded, similar productivity levels as reported in highly productive Sitka spruce stands in Pacific North West, Ireland and Scotland. In comparison to Downy birch stands the biomass production gain in Sitka spruce is in the range from 3 to 5 folds. Several of the minor used non-native tree species like Japanese larch, European larch, Siberian stone pine, Douglas fir, Western hemlock and Lodgepole pine are locally shown to more than double the biomass production compared to Downy birch. For the other non-native species examined in these coastal sites biomass production compared to Norway spruce is similar or lower. Our results suggest that Sitka spruce and some other non-native tree species rarely applied in coastal Norway have a great potential for increased biomass production and as a tool for increased carbon sequestration during the green shift.
\end{abstract}

Keywords: non-native versus native tree species, biomass production, growth potential, coastal norway
Volume I Issue 3 - 2017

\author{
Øyen BH,' Nygaard PH ${ }^{2}$ \\ 'Coastal Forestry, Norway \\ ${ }^{2}$ Norwegian Institute of Bioeconomy Research, Norway
}

Correspondence: Per Holm Nygaard, Norwegian Institute
of Bioeconomy Research, I430 Ås, Norway, Tel +479| I38।38, Email PHN@nibio.no

Received: December 14, 2017 | Published: December 22, 2017

\section{Introduction}

Deliberate anthropogenic introductions of exotic trees to NW Europe are not particular new; traces of planting near the castles and monasteries dates back to the late Roman period and early medieval age. ${ }^{1}$ The first reforestation and forest culture initiatives in Norway were taken in the $1740 \mathrm{~s},{ }^{2-5}$ and larch plantations in western Norway were established in the $1780 \mathrm{~s} .{ }^{6}$ However, the ideas of afforestation evolved rather slowly. Interest for foreign exotic species boosted after the 1870 s, when the first forest nurseries and "trials" were established in western Norway. ${ }^{5}$

During the 1930s-1950s, the area under forest plantation in Westand North Norway was being extended, following Government forest policy, where the main driver was the lack of wooden resources, especially in coastal districts. ${ }^{2,5}$ The bulk of the afforestation areas in the fjord-areas were planted with Norway spruce (Picea abies) and the coastal sites with Sitka spruce (Picea sitchensis). ${ }^{5}$ A lively interest in the timber potential of other species led to the planting, in various parts of the country, of a number of c. 25 species. ${ }^{3,4,7,8}$ Among them: Lutz spruce (Picea x lutzii), Engelmann spruce (Picea engelmannii), White spruce (Picea glauca), Western hemlock (Tsuga heterophylla), Western red cedar(Thuja plicata), Douglas fir (Pseudotsuga menziesii), Grand fir (Abies grandis), European fir (Abies alba), Siberian fir (Abies sibirica), Mountain fir (Abies lasiocarpa), Siberian stone pine (Pinus sibirica), Mountain pines (Pinus uncinata, Pinus mugo), Lodgepole pine (Pinus contorta), European larch (Larix decidua), Siberian larch (Larix sibirica), Japanese larch (Larix kaempferii) and Hybrid larch (Larix $x$ eurolepis). In addition, some broadleaved species like ash
(Fraxinus excelsior), oak (Quercus ssp), beech (Fagus sylvatica), poplars (Populus ssp.) and silver birch (Betula pendula) were tested. The early growth for some of the conifers appeared sufficiently promising for their planting to be extended, and by the 1960 s, the prethicket growth in some of the earliest plantations was characterized as outstanding. ${ }^{7}$

At the same time, however, there were doubts expressed as to the value of the timber from the faster growing plantations and to their ability to withstand harsh climate, damaging agents, pest and diseases outbreaks in comparison to indigenous tree species. ${ }^{9,10}$ Consequently, in the 1960s and 1970s the first investigations of wood properties, ${ }^{11}$ and susceptibility of different species to Heterobasidion heart rot, were carried out. ${ }^{7,12}$

In the late 1970s, 1980s and 90s great changes in the Norwegian countryside took place; reduction in number of farms, lack of labor in forest sector, and a general decrease in the interest for cultivation of potential forested land coupled with concern about ecological effects from afforestation. ${ }^{5,13}$ The utility prospect of land and land use was challenged with a conservation philosophy, especially put forward by environmentalists. These elements, but also the fact that the afforestation plan was nearly completed led to a severe decrease in planting up to the turn of the millennium. During the last seventeen years cautiousness and skepticism has been the guiding stars in Norwegian policy regarding tree planting of non-natives. The skepticism and an exceptional high-cost of labor have now led to the lowest use of exotic seedlings in afforestation in Norway ever since the 1920s (Table 1). 
Table I Area (in 100 hectare) planted per decade of non-native tree species in Norway. Source:Annual reports, Forest Director, I875-20I5. The area arises from the number of planted seedlings, and density recommendations given by the authorities

\begin{tabular}{lllllllllll} 
Decade & -1920 & $1920 \mathrm{~s}$ & $1930 \mathrm{~s}$ & $1940 \mathrm{~s}$ & $1950 \mathrm{~s}$ & $1960 \mathrm{~s}$ & $1970 \mathrm{~s}$ & $1980 \mathrm{~s}$ & $1990 \mathrm{~s}$ & $2000 \mathrm{~s}$ \\
Area & 8 & 24 & 16 & 3 & 76 & 188 & 292 & 118 & 69 & 6 \\
\hline
\end{tabular}

Up to present about 50000 hectares of exotics have been planted in the West-Norway and 20,000ha in North-Norway, most in coastal sites on private ground. ${ }^{8,14}$ Approximately 10,000 hectares is planted in inland conditions in southeast and central Norway, mostly Lodgepole pine but also some Siberian larch and Engelmann spruce. In total, $0.6 \%$ of the present national forest land is cultivated with exotics. ${ }^{15}$ However, on some islands in western districts the relative proportion of exotics could be more than half the total forest covered area and the only economically sustainable alternative. ${ }^{16}$ Sitka spruce is the superior choice, occupying 50.000 ha or two thirds of the scattered plantation area of all exotics, mainly applied along the harsh Atlantic west coast. ${ }^{8,17}$ Other species like Japanese and European Larch, Douglas fir, Western hemlock, Western red cedar and various fir species play minor roles, are mostly planted as small-scale plantations in warmer fjord sites. The fir species, especially Mountain fir and Caucasian fir is increasing their popularity as Christmas trees. ${ }^{14}$

Some decades ago selected exotic tree species were important research objects in forest research, and investigated in numerous trials. National breeding programs were launched for Sitka spruce, Siberian larch, Lodgepole pine and Lutz spruce in the 1960, 70s and 80s. Other species like Douglas fir, Western red cedar and Dunkeld (Hybrid) larch were classified to locally have a large potential in afforestation with emphasis on growing special wood qualities. ${ }^{10,18}$

Much of the ongoing concerns directed towards the exotic trees and their risk for spreading seems to rely on experiences from the southern hemisphere. Despite lack of data, gaps in knowledge and no proper designed spreading investigations for trees, several of the introduced conifers have been placed on the "Norwegian black list" as "high risk species" mainly because of the precautionary principle. ${ }^{19}$ The lack of scientific basis for the work and the inconsistency in the criteria set and usage or interpretation of data has previously been criticized. ${ }^{17}$

The skepticism towards exotic tree-species in Norway reached so far, its highest level in 2012, when legislation according to the "Nature diversity act" and very strict regulations herein for re-planting and for establishing new plantations. The effect of this policy has not been analyzed. However, over the last 5years an increasing mismatch between cutting area and re-cultivated area is reported. In contrast to worries about nature conservation, harvesting of old plantations of exotics often show favorable financial returns compared to alternative land uses and use of indigenous species. ${ }^{20,21}$ A national pilot project for carbon sequestration benefits of new woodland expansion in coastal sites was launched in 2015; however, only native tree species were considered.

Another issue, although not much debated yet in Norway, is how and when to start the adaptation of forest management to climate change, which ultimately poses new and great challenges to the hegemonic indigenous species conservation discourse.

Growth and yield results from long-term growth trials with exotic tree species in Norway have previously been published in papers, textbooks and reports from the Norwegian Forest Research Institute..$^{5,7,10,12,16,17,22,23}$ However, for several of the species from small- scale plantations the comparisons with indigenous species regarding biomass production over a full rotation is rather limited. In this paper, we used long-term growth trials to analyze biomass production for some selected non-native tree species. The main issue addressed is to compare biomass production in non-native trees over one rotation period with the native tree species, Downy birch, Scots pine or Norway spruce.

\section{Materials and methods}

\section{Forest research areas}

For quantifying gains or losses in biomass production connected to the choice of tree species, we analyzed absolute and relative difference between neighboring stands with similar growth conditions. An identical approach has previously been used for growth comparisons of silvicultural systems, tree species and provenance choices. ${ }^{23-25}$ From the forest trial revision bank managed by the Norwegian Forest Research Institute (NIBIO) we selected and utilized growth and yield data from long-term plots located in afforestation districts. Three research forests in coastal Norway covering trials of native and nonnative species and stand ages mainly above 70 years was chosen for this case study; Alstahaug in Nordland County, Stend in Hordaland County and Lomeland in Rogaland County (Figure 1).

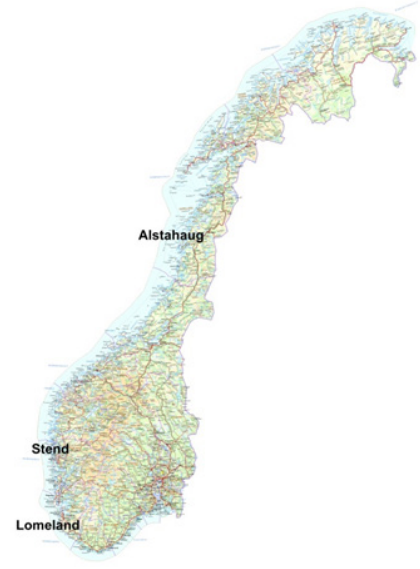

Figure I Location of the research areas in Norway applied in this study. Alstahaug, Stend and Lomeland.

The northern site Alstahaug is located near the Arctic Circle at latitude $66^{\circ} \mathrm{N}$, the southernmost site is located at $59^{\circ} \mathrm{N}$. Annual average number of growth days $\left(>6^{\circ} \mathrm{C}\right)$ is 200 for Stend and Lomeland, 180 in Alstahaug. All the plots are situated below $100 \mathrm{~m}$ above sea level. The neighbor stands were located within a few hundred meters apart from each other showing the same exposure and with similar initial soil conditions and vegetation type. The trials in Alstahaug and Stend were classified to small fern/low herb vegetation at medium to rich sites. In Lomeland the soils are podsols and the field layer is dominated by heather and bilberry.

Major disturbances from wind-throw, defoliation from insect outbreaks and winter-drought where not reported for any of the sites. The sizes of the temporary plots are $250 \mathrm{~m}^{2}$, and the long-term plots in 
the range from 0.06 to 0.14 hectares. Number of revisions in the longterm plots varies from 6 and up to 18 .

\section{Data}

In site Alstahaug (A) data from seven long-term trials were analyzed. Temporary plots were established in 78-90 year old stands of Mountain Fir (MF), Japanese larch (JL), Western hemlock (WH) and Downy birch (DB). For Lutz spruce (LS, Picea x lutzii Little) we applied revision data from a 20 -year-old offspring trial. From stand data we applied the Sitka spruce (SS) growth model ${ }^{18}$ to estimate growth figures and a yield table up to stand age 80years.

In site Stend (S) 22 long-term trials were included. Temporary plots included stands over 80years of Lawson cypress (LC), Western red cedar (WRC) and oak (QR). Most of the oak stand belongs to Penduculate oak $(Q$. robour $)$, but a few Sessile oaks $(Q$. petrea) was identified. The stands of Silver birch (SB), Downy birch (DB) and Common alder (CA) were 32, 49 and 22years old, respectively. The prolonged development was simulated by use of initial stand data from the last revision and the Norwegian stand growth model for unthinned birch. ${ }^{21,26}$ In site Lomeland (L) 22 long-term trials were included.
In total, 49 long term trials with time-series data and 15 temporary plots was applied in the study. These long-term trials and most of the temporary plots comprising many of the minor applied species have at least reached $90 \%$ of a normal economically based rotation age for the site. Quite many of the exotic species show a rather stabile and prolonged current annual increment (CAI) in high ages, so we were not yet in position to present any real comparison of the actual maximum mean annual increment (MAI). Instead, we applied the observed total production figures up to the last revisions. We have assumed that observed MAI $\sim \mathrm{LYC}$, local yield class. For the volume calculations, we applied the species-specific regional or national equations. ${ }^{27,28}$ Various growth figures herein: total volume production over bark, mean tree diameter, Lorey's mean tree height $\left(\mathrm{H}_{\mathrm{L}}\right)$, number of trees per hectare; combined with specific wood gravity, biomass expansion figures or biomass functions (Table 2) were used to estimate aboveground dry weight production in tons per hectare. The expansion factor for mature stands varied from 0.39 in Mountain fir and up to 0.67 in European beech. Cumulative sequestration in aboveground biomass was calculated as the total production for a stand at age 80year multiplied with the expansion factor (Table 2) for the species.

Table 2 Nominal specific gravity (NSG) in stem wood from stands and biomass expansion factors or aboveground biomass functions applied for these species when grown in a forestation areas in West- and North-Norway. The NSG-figures ${ }^{5,11,47,48}$ are supplemented with unpublished figures from western Norway (NIBIO). Native species in bold

\begin{tabular}{|c|c|c|c|c|}
\hline Tree species & Scientific name & NSG ( 1 ) (Tons $\left.\mathrm{m}^{-3}\right)$ & BEF,AGB (2) & $E F, I \times 2$ \\
\hline Caucasian Fir (CF) & Abies nordmanniana Steven Spach & 0.36 & 1.3 & 0.47 \\
\hline Common Alder (CA) & Alnus glutinosa L. Moench. & 0.39 & 1.2 & 0.47 \\
\hline Douglas Fir (DF) & Psedotsuga menziesii Mirb. Franco & 0.43 & 1.3 & 0.56 \\
\hline Downy Birch (DB) & Betula pubescens Ehrh. & 0.5 & 31,33 & \\
\hline European Beech (EB) & Fagus sylvatica $\mathrm{L}$. & 0.56 & 1.2 & 0.67 \\
\hline Eu. Silver Fir (EF) & Abies alba Mill. & 0.36 & 1.3 & 0.47 \\
\hline European Larch (EL) & Larix decidua Mill. & 0.45 & 1.25 & 0.56 \\
\hline Grand Fir (GF) & Abies grandis D. ex D. Don. Lindl. & 0.32 & 1.3 & 0.42 \\
\hline Japanese Larch (JL) & Larix kaempferi Lamb. Carr & 0.43 & 1.25 & 0.54 \\
\hline Lawson Cypress (LC) & Chamaecyparis lawsoniana Parl. & 0.33 & 1.25 & $0.4 \mathrm{I}$ \\
\hline Lodgepole Pine (LP) & Pinus contorta Doug. ex ILoundon & 0.38 & 1.25 & 0.48 \\
\hline Lutz Spruce (LS) & Picea $x$ lutzii Little & 0.39 & 1.25 & 0.49 \\
\hline Mountain Pine (MP) & Pinus uncinata Domin. & 0.5 & 1.25 & 0.63 \\
\hline Mountain Fir (MF) & Abies lasiocarpa Hook. Nutt. & 0.31 & 1.25 & 0.39 \\
\hline Noble Fir (NF) & Abies procera Rehder & 0.33 & 1.3 & 0.43 \\
\hline Norway Spruce (NS) & Picea abies L. Karst. & 0.38 & 31,34 & \\
\hline Oak (QR) & Quercus robour $\mathrm{L}$. & 0.55 & 1.2 & 0.66 \\
\hline Scots Pine (SP) & Pinus sylvestris $\mathrm{L}$. & 0.42 & 34,50 & \\
\hline Siberian Fir (SF) & Abies sibirica Ledeb. & 0.33 & 1.25 & 0.41 \\
\hline Sib. stone Pine (SCP) & Pinus sibirica Du Tour. Kry. & 0.42 & 1.25 & 0.53 \\
\hline Silver Birch & Betula pendula Roth. & 0.5 & 31,33 & \\
\hline Sitka Spruce (SS) & Picea sitchensis Bong. Carr. & 0.36 & \multicolumn{2}{|c|}{$A G B=0.3664 * d^{2.1053}$} \\
\hline W. Hemlock (WH) & Tsuga heterophylla Raf. Sarg. & 0.41 & 1.3 & 0.53 \\
\hline W. Red Cedar (WRC) & Thuja plicata Donn ex. D. Don & 0.33 & 1.25 & 0.41 \\
\hline White Fir (WF) & Abies concolor Lindl. ex. Hildebr. & 0.34 & 1.3 & 0.44 \\
\hline
\end{tabular}

Western hemlock, LYC $=20 \mathrm{~m}^{3} \mathrm{ha}^{-1} \mathrm{yr}^{-1}$. Rotation age $80 \mathrm{yrs}$. Total production $1600 \mathrm{~m}^{3} \mathrm{ha}^{-1}$. Above ground biomass production, $\mathrm{I} 600 \times 0.53=848$ tons dry matter per ha. Within 80 years rotation period the average aboveground annual biomass accumulation in the stand is 10.6 tons ha ${ }^{-1} \mathrm{yr}^{-1}$ corresponding to $\mathrm{c}^{-5} .3$ tons $\mathrm{C}$ $\mathrm{ha}^{-1} \mathrm{yr}^{-1}$ or 19.4tons $\mathrm{CO}_{2}$-eqv. ha- $\mathrm{yr}^{-1}$ 


\section{Statistical methods}

Yield and biomass figures were compared at a fixed stand age of $80 y e a r s$. In the comparisons we utilised growth figures for the longterm plots or temporary plots around 80years directly. The total stand age (age in years from seeding) of neighbour plots could vary a few years. To achieve a balanced comparison to the same total age we performed a linear interpolation between revisions or we extrapolated the figures with a maximum five years.

For the young temporary plots, we applied a growth model system which has been described in general terms by Braastad. ${ }^{26} \varnothing y e n^{17}$ has described the procedures used for growth modelling more in detail. The system requires as a minimum input data comprising information on standing volume per hectare, site index (H40) and stand age. Measurements acquired when the trial was established were used as the starting point for the mathematical simulation. Each increment period is five years. Stem volumes for individual trees on the plots summed up to stand figures per hectare were estimated using models from Bauger ${ }^{27}$ and Øyen \& Tveite. ${ }^{28}$

We applied a paired-design (Mann-Whitney-Wilcoxon) to test whether a randomly selected value from one sample of site index $\left(\mathrm{H}_{40}\right)$ in a tree species will be less than or greater than a randomly selected value from another tree species. We assumed that all the observations from both groups are independent of each other.

For the presentations of yield curves, local yield class $\left(\mathrm{m}^{3} \mathrm{ha}^{-1} \mathrm{yr}^{-1}\right)$ and aboveground biomass (tons dry matter $\mathrm{ha}^{-1} \mathrm{yr}^{-1}$ ) average values are shown.

\section{Results and discussion}

Site index $\left(\mathrm{H}_{40}\right)$ display a great variation between the trials and especially between the tree species. For the plantations of Sitka spruce (SS) and Norway spruce (NS) on rich soils the gain in $\mathrm{H}_{40}$ is in the range from 5.4 up to $9.7 \mathrm{~m}$ in comparison with native stands of Downy birch (DB) or Scots pine (SP). The observed differences from the rich sites are similar to gains/losses reported from other studies in western Norway. ${ }^{23,29}$ The difference in poorer soils (L-site), soils with growth check, is less pronounced. Such result is also supported by former studies in the region, ${ }^{8,10,12}$ For the main four species applied in coastal forestry (NS, DB, SP and SS) the relative growth figures and the general growth pattern turned out to be rather consistent.

The highest average volume production for the site A in North Norway was found in Sitka spruce (SS, prov. Petersburg, Alaska) with a LYC of $14.4 \mathrm{~m}^{3} \mathrm{ha}^{-1} \mathrm{yr}^{-1}$ and site index of $\mathrm{H}_{40}=20 \mathrm{~m}$. The neighbor stand of native Downy birch (DB) showed a site index of $\mathrm{H}_{40}=11 \mathrm{~m}$ corresponding to a LYC of $2.7 \mathrm{~m}^{3} \mathrm{ha}^{-1} \mathrm{yr}^{-1}$. The Siberian stone pine (SCP), Japanese larch (JL) and Norway spruce (NS) had the most rapid start; however, when stand age exceeds 50years Sitka spruce (SS) was superior compared to the other species (Figure 2). In the coastal, south-facing sheltered site, Norway spruce (NS) in average produced $7.5 \mathrm{~m}^{3} \mathrm{ha}^{-1} \mathrm{yr}^{-1}$. The relative difference in yield class between Sitka spruce (SS), Norway spruce (NS), Downy Birch (DB) in percent was: $100,61,26$, respectively.

Although far below Sitka spruce (SS), the Caucasian (Nordmann) fir (NF), Japanese larch (JL) and Lutz spruce (LS), had a substantial higher production than native Norway spruce (NS, local provenance). Mountain fir (MF), White fir (WF), Western hemlock (WH) and Siberian stone pine (SCP) showed a rather similar biomass production compared to Norway spruce (NS), (Figure 3).

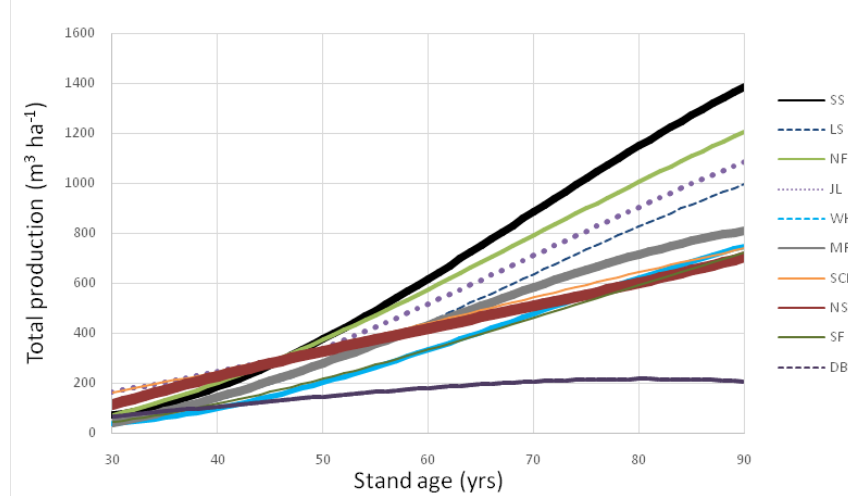

Figure 2 Yield curves for tree species in site A. Temporary plots and simulations with hatched line and observations from long-term experiments with solid lines. For species abbreviations see Table 2.

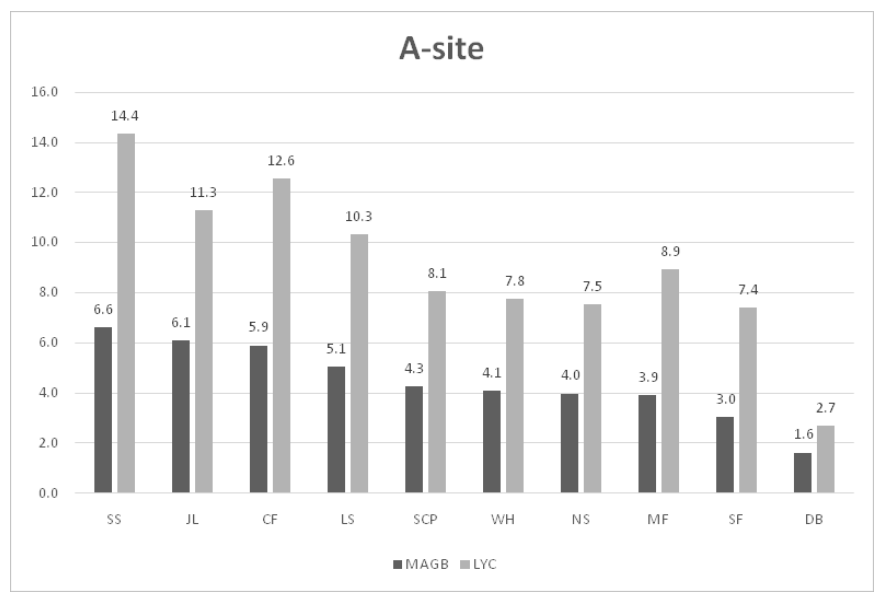

Figure 3 Local yield class (LYC, $\mathrm{m}^{3} \mathrm{ha}^{-1} \mathrm{yr}^{-1}$ ) and average aboveground biomass production (MAGB, tons dry matter ha-1 $\mathrm{yr}^{-1}$ ) at reference age 80 years (black bar). For species abbreviations see Table 2 .

For the trials in S-site the Grand fir stand (GF, prov. BC, $800 \mathrm{~m}$ a s 1) had the most superior volume production with a LYC of $27 \mathrm{~m}^{3}$ $\mathrm{ha}^{-1} \mathrm{yr}^{-1}$ and a biomass production of 10.4 tons dry matter $\mathrm{ha}^{-1} \mathrm{yr}^{-1}$. Sitka spruce (SS, prov. Petersburg, Alaska) ranged as number one in biomass with a LYC of $22.0 \mathrm{~m}^{3} \mathrm{ha}^{-1} \mathrm{yr}^{-1}$ and 10.6 tons dry matter ha- $\mathrm{yr}^{-1}$. These two species were the most productive (Table 3). In contrast, a neighbor stand of beech (EB) showed a biomass production of 4.2 tons dry matter $\mathrm{ha}^{-1} \mathrm{yr}^{-1}$. The relative difference in biomass sequestration between Sitka spruce (SS), Norway spruce (NS), Scots pine (SP), Downy birch (DB) in percent above-ground biomass production was $100,69,25$, and 23 , respectively.

Douglas fir (DF) and Western hemlock (WH) had a slightly higher MAGB-production than Norway spruce, whereas Silver fir (EF), Lawson cypress (LC), Japanese larch (JL) and Western red cedar (WRC) were slightly lower. The indigenous species, properly managed stands of Silver birch (SB), Downy birch (DB), Scots pine (SP) and Oak (QR), had a rather low biomass production, below 3.6tons per hectare and year. This is less than $50 \%$ of the MAGB in Norway spruce (NS). The native common alder (CA) has achieved a biomass production of two thirds of Norway spruce (NS).

For the southernmost research area, the L-site (Table 4, right), the local yield class is much lower in comparison to the other two research areas. Sitka spruce (SS) showed the highest LYC in the range from 7.2 to 11.6 and a mean of $9.5 \mathrm{~m}^{3} \mathrm{ha}^{-1} \mathrm{yr}^{-1}$. However, both Norway spruce 
(NS) and Sitka spruce (SS) -plots on former Calluna-heathland in the area is submitted to growth-check, which causes a delayed development. European beech (EB) has achieved a similar biomass production as Sitka spruce (SS) up to age 80years, 4.7 tons dry matter $\mathrm{ha}^{-1} \mathrm{yr}^{-1}$. The relative difference between Sitka spruce (SS), Norway spruce (NS), Scots pine (SP), Downy Birch (DB) in percent above ground biomass production was $100,62,70$, and 32 , respectively.

Table 3 Mean difference in site index $\left(\mathrm{H}_{40}\right)$ for the main afforestation species Sitka spruce (SS), Norway spruce (NS), Downy birch (DB) and Scots pine (SP) at three different sites

\begin{tabular}{rrrrrrr}
\hline $\begin{array}{l}\text { Difference } \\
\text { SS-DB }\end{array}$ & $\begin{array}{l}\text { Difference } \\
\text { NS-DB }\end{array}$ & $\begin{array}{l}\text { Difference } \\
\text { SS-NS }\end{array}$ & $\begin{array}{l}\text { Difference SS- } \\
\text { SP }\end{array}$ & $\begin{array}{l}\text { Difference NS- } \\
\text { SP }\end{array}$ & $\begin{array}{l}\text { Difference } \\
\text { SSP-DB }\end{array}$ \\
\hline A-site & $9.0 * * *$ & $5.4 * * *$ & $4.2 * * *$ & - & - & - \\
S-site & $9.7 * * *$ & $7.3 * * *$ & $2.9 * * *$ & $9.5 * * *$ & $7.1 * * *$ & $0.2^{\text {ns }}$ \\
L-site & $5.6 * * *$ & $4.2 * * *$ & $3.0 * * *$ & $5.5 * * *$ & $2.9 * * *$ & $0.7^{\text {ns }}$ \\
\hline
\end{tabular}

Mann-Whitney-Wilcoxen-test $* * *$ Significance level $<0,00 \mathrm{I}$ ns, not significant

Table 4 Local yield class (LYC, $\left.\mathrm{m}^{3} \mathrm{ha}^{-1} \mathrm{yr}^{-1}\right)$, average aboveground biomass production (MAGB, tons dry matter ha-1 $\left.\mathrm{yr}^{-1}\right)$ at reference age 80 years (black bar). Rel $\%$ denotes MGAB for the species in percent of Sitka spruce at the same site. For species abbreviations see Table 2. Native species in bold

\begin{tabular}{|c|c|c|c|c|c|c|c|c|c|}
\hline \multirow{2}{*}{ Species } & \multicolumn{3}{|c|}{ A-Site } & \multicolumn{3}{|c|}{ S-Site } & \multicolumn{3}{|c|}{ L-Site } \\
\hline & LYC & MGAB & Rel\% & LYC & MGAB & Rel\% & LYC & MGAB & Rel\% \\
\hline SS & 14.4 & 6.6 & 100 & 22 & 10.6 & 100 & 9.5 & 4.7 & 100 \\
\hline NS & 7.5 & 4 & 61 & 14.4 & 7.3 & 69 & 5.6 & 2.9 & 62 \\
\hline LS & 10.3 & 5.1 & 77 & - & - & - & - & - & - \\
\hline DB & 2.7 & 1.7 & 26 & 4.1 & 2.4 & 23 & 2.4 & 1.5 & 32 \\
\hline SB & - & - & - & 6.5 & 3.5 & 34 & - & - & - \\
\hline GF & - & - & - & 27 & 10.4 & 98 & - & - & - \\
\hline $\mathrm{CF}$ & 12.6 & 5.9 & 89 & - & - & - & - & - & - \\
\hline EF & - & - & - & 14 & 6.4 & 60 & 6.8 & 3.1 & 66 \\
\hline SF & 7.4 & 3 & 45 & - & - & - & - & - & - \\
\hline$N F$ & - & - & - & 15.4 & 6.5 & 61 & - & - & - \\
\hline MF & 9.1 & 3.6 & 54 & & & & & & \\
\hline WF & 8.9 & 3.9 & 59 & - & - & - & - & - & - \\
\hline WH & 7.8 & 4.1 & 62 & 13.7 & 7.4 & 70 & - & - & - \\
\hline DF & - & - & - & 14.5 & 7.7 & 73 & - & - & - \\
\hline LC & - & - & - & 15.5 & 7.1 & 67 & - & - & - \\
\hline$J \mathrm{~L}$ & 11.3 & 6.1 & 92 & 12.2 & 6.3 & 59 & - & - & - \\
\hline EL & - & - & - & - & - & - & 6.1 & 3.6 & 77 \\
\hline WRC & - & - & - & 15 & 5.4 & 51 & - & - & - \\
\hline $\mathrm{CA}$ & - & - & - & 10.2 & 4.8 & 45 & - & - & - \\
\hline EB & - & - & - & 6.8 & 4.2 & 40 & 7.5 & 4.7 & 99 \\
\hline QR & - & - & - & 5.5 & 3.6 & 34 & - & - & - \\
\hline SP & - & - & - & 5 & 2.7 & 25 & 6.1 & 3.6 & 70 \\
\hline MP & - & - & - & - & - & - & 5.5 & 3.4 & 72 \\
\hline LP & - & - & - & - & - & - & 7.2 & 3.9 & 83 \\
\hline SCP & 8.1 & 4.3 & 65 & - & - & - & - & - & - \\
\hline
\end{tabular}

Except for Downy birch (DB), Silver birch (SB), Norway spruce (NS), Sitka spruce (SS) and Scots pine (SP) for which we have test data available, the uncertainty connected to biomass expansion factors and/or specific gravity of wood should be further elaborated in extended biomass studies. The considerable expense of developing new biomass equations argues for the utilization of the maximum extent practicable biomass equations, and data that have already been developed. Unfortunately, equations and data were typically developed to represent specific geographical regions, ranges of tree sizes or components, and there is no practical way to objectively assess bias of existing equations. ${ }^{30}$ Several studies underline that care must be taken when projections are made; however, equations developed from 
stands growing in proximity, similar physiogeographic conditions and matching range of size may help in choosing an equation with a good fit - to reduce uncertainty. ${ }^{31}$

This work should therefore be looked upon as preliminary - new calculations should be encouraged after the extended menu and tools of biomass functions/BEFs and accurate wood studies and other biomass components are accomplished. We have applied BEFs and biomass functions previously utilized in neighbor countries in NW Europe: Great Britain, ${ }^{32}$ Sweden, ${ }^{33}$ Finland, ${ }^{34}$ Iceland, ${ }^{35}$ Denmark, ${ }^{36}$ coupled with wood gravity investigations from West- and North Norway. The wood studies and the BEFs seem to be resulting from stands of varying densities and ages, so the applicability in other stand types is uncertain. However, all the long-term and temporary trials applied for comparisons in this study are dense, high stocked and close to the self-thinning limit. Most of the long-term trials and temporary plots are mature stands. To avoid overestimation of biomass we have applied rather low biomass expansion factors values for the dense conifer plantations. For instance, Johnsen ${ }^{37}$ found that average BEF for Sitka spruce from two middle-aged stands in Westand North Norway was 1.64. Such a default BEF-value will probably lead to a severe overestimation of biomass in mature, volume-rich stands. Anon ${ }^{38}$ found that Marklunds functions ${ }^{31}$ for Norway spruce fitted well for a 45year old SS plantation in Steigen, North Norway. However, test data from 16 dominant and co-dominant trees from West- and North Norway indicate that the large sized trees are over-estimated with some $15-20 \%$ by use of this function. The BEF functions from Ireland, ${ }^{39,40}$ Scotland, ${ }^{32}$ Sitka spruce in $\mathrm{US}^{41}$ and SS in Denmark by Nord-Larsen, ${ }^{36}$ all slightly underestimate the MAGB. The Icelandic SS function ${ }^{35}$ fits pretty well for small sized trees, but seems to underestimate MAGB for larger trees. The best overall fit we found by use of a SS-function from British Colombia, ${ }^{42}$ and a recalibrated biomass function was applied in the present work (Table 2).

Based on three research areas and time series from 49 long-term trials and 15 temporary plots our interpretation is that Sitka spruce in general is the most efficient biomass producer over a normal first forest rotation in coastal sites in West- and North Norway. Compared to Downy birch the biomass production in SS is 3 to 5 -fold. In comparison, Norway spruce produces about two thirds of the aboveground biomass within 80years. We emphasize that all the three research areas are sheltered for heavy westerly winds. In windswept sites the differences have former been demonstrated to be larger because NS is shown to suffer from winter drought and saltspray damages. ${ }^{7,9,23}$

Grand fir (GF) is indicating a rather similar rate of biomass production compared to Sitka spruce in the most productive areas in SW Norway, and European beech seems to be able to compete in biomass production with SS on nutrient-poor, sandy soils. So we emphasize that there might be certain small-scale locations where other tree species and provenances could compete with SS in coastal sites. However, based on the present study and former published results from tree species trials and comparisons in West Norway; Sitka spruce (SS) is superior in a wide ecological amplitude. It is an interesting feature, that the yield class and biomass production reported in West Norway with average MAGB up to 10-11tons per year and current aboveground biomass sequestration up to 20tons hectare and year, are matching well to similar upper boundary levels reported in Western hemlock/Sitka Spruce stands in Pacific Northwest. ${ }^{43}$ These results also match highly productive plantations in Ireland and Scotland. ${ }^{44}$ Although few research stands is available, in stands with 2 nd rotation of Sitka spruce in western Norway LYC tends to be $20-50 \%$ higher than in first rotation. This is due to better knowledge of suitable (adaptive) materials and no growth check.

The results from our study clearly demonstrates that several of the introduced conifers perform better than native Norway spruce (NS) although the gains in biomass are smaller than for Sitka spruce (SS), mostly within 25per cent. Japanese larch (JL), European larch (EL), Lutz spruce (LS), European silver fir (EF), Caucasian fir (NF), Siberian stone pine (SCP), Douglas fir (DF), Western hemlock (WH) and Lodgepole pine (LP) are showing an increased biomass production compared to Norway spruce (NS) and certainly a great gain in comparison to Downy birch (DB). Lodgepole pines (LP) are $10 \%$ higher in aboveground biomass production compared to Scots pine (SP) at the Lomeland site. In other sites on mineral soils in West Norway the gains in applying Lodgepole pine has been $30-60 \%$ in volume and c. $25 \%$ in aboveground biomass, so the poor performance in Lomeland could be an artefact of a suboptimal provenance. Especially the material from Skagway, Alaska, has performed very well in species and provenance trials on poor sites on mineral soils and bogs in West Norway. ${ }^{10,16}$ Scots pine and Mountain pine have achieved a similar biomass production as Norway spruce on the poorest site, Lomeland. Here there are strongly competitive weed species such as Molinia caerulea, Vaccinium myrtillus and Calluna vulgaris, and growth check was noticed for NS and SS in the initial phase. For the indigenous broadleaves, except for European beech (EB), the biomass production turned out to be substantially lower than for Norway spruce over a full rotation. In general, the growth figures in this study matches the differences found in a neighbor pairs on mineral soils and drained bogs elsewhere in West Norway. ${ }^{16,23,24}$ Similar relative differences in biomass production between treespecies are also reported in middle-aged stands in Denmark ${ }^{45}$ and are indicated in simulations based on Swedish results. ${ }^{46}$

The study illustrates that by doing a careful selection of species suitable for the site it is possible to increase aboveground biomass production and carbon sequestration in coastal areas by many folds without use of fertilizers or other aims connected to intensive forestry. ${ }^{29,46}$ With a projected doubling of demand of bioenergy over the next decades in Europe, and projected changes in growth conditions, this calls for prolonged and extended long-term research in tree species choice. ${ }^{47-51}$

\section{Conclusion}

A case study from coastal Norway including records from neighbor long-term yield trials in three forest research areas merged with preliminary biomass expansion factors deduced from neighbor countries and coupled with specific wood gravity studies show:

a. The non-native Sitka spruce is showing a 3 to 5 -fold gain in aboveground biomass production compared to native Downy birch in coastal sites in West- and North Norway over a rotation age of 80 year.

b. Sitka spruce is producing $30-40 \%$ more aboveground biomass compared to native Norway spruce over a forestry rotation of 80 years, in sheltered coastal sites.

c. The non-natives; Japanese larch, European larch, Lutz spruce, Silver fir, Caucasian fir, Siberian stone pine, Douglas fir, Western hemlock and Lodgepole pine, have been shown to exceed the native species Scots pine and Downy birch in biomass production, and are locally competing with Norway spruce in biomass sequestration. 
d. Except for European beech on the poor soils the indigenous broadleaved species generally show a much lower biomass production compared to Norway spruce and Sitka spruce.

e. Several non-native conifer species has a great potential in increasing the aboveground dry matter production in Westand North Norway. This could be utilized directly in energy production or it could be seen as an additional effect of valuable timber production to increase carbon sequestration in productive coastal sites.

\section{Acknowledgments}

The study was financed with grants from the Norwegian Research Council (SGB-Biomass) and Nordic Research Council (Enerwood). Hans Nyeggen, NIBIO, was involved in the fieldwork for the S \& L-sites (last revision) and Stig Støtvig (NIBIO) contributed in the data management.

\section{Author contributions}

Bernt-Håvard Øyen end Per Holm Nygaard conceived and designed the experiments; and have analyzed the data and written the paper jointly together.

\section{Conflicts of interest}

The authors declare that there is no conflict of interest.

\section{References}

1. Rackham O. Trees and woodland in the british landscape: The complete history of Britain's trees, woods \& hedgerows. London, England: Phoenix Press; 2001

2. Fryjordet T. The history of forest administration in Norway. I. Forest conditions, forestry and forest administration up to the 1850s. Oslo, Norway: Ministry of Agriculture and State Forest Norway; 1992.

3. Hagem O. Experiments of tree species from western USA and Canada. Norway: Communication Forest Research Institute of West Norway; 1931. $217 \mathrm{p}$.

4. Hagem O. Foreign tree species in Norwegian forestry. Tidsskrift for Skogbruk, Norway; 1918. 28 p.

5. Øyen BH. Costal forestry. Potential and challenges the coming decades. Norway: Norwegian Forest and Landscape Research Institue; 2008. 54 p.

6. Øyen BH. Growing larch in Norway-the history. Skogforsk, Norway; 2006. 15 p.

7. Robak H. 50years anniversary. Norway: Communication Forest Research Institute of West Norway; 1996. 143 p.

8. Øyen BH, Andersen HL, Myking T, et al. Ecological traits for 11 selected conifer species in Norway. Norway: Norwegian Forest and Landscape Research Institue; 2009. 43 p.

9. Magnesen S. Injuries on forest trees related to choice of tree species and provenances: A literature survey of a one hundred year epoch in Norwegian forestry. Skogforsk, Norway; 1992. p. 1-46.

10. Magnesen S. Trials and experiments with coniferous trees and provenances in western Norway. Skogforsk, Norway; 2001. 1-20p.

11. Klem G. Variation in density in foreign species and Norway spruce in SW Norway. Norway: Communication Forest Research Institute of West Norway; 1965. p. 139-169.

12. Øyen BH, Øen S. Choice of tree species on root rot infested soilsHøylandskomplekset, Rogaland county. Preliminary results. Norway: Norwegian Forest and Landscape Research Institue; 2004. 18 p.
13. Almås R. Norwegian agricultural history, 1920-2000. Samlaget: Oslo, Norway; 2002.

14. Tomter S. Sustainable forestry in Norway. Norway: Norwegian Forest and Landscape Research Institue; 2014. 241 p.

15. Øyen BH, Andersen HL, Myking T, et al. Evaluation of „Blacklist Norway 2006"- selected conifer species. Norway: Norwegian Forest and Landscape Research Institue; 2009. 13ps.

16. Brække FH. Choice of tree species and fertilizer program for drained bogs in Central- and North Norway. Norway: Communication Forest Research Institute of West Norway; 1986. p. 165-176.

17. Øyen BH. Growth models for Sitka spruce (Picea sitchensis Bong Carr.) stands in western Norway. Norway: Norwegian Forest and Landscape Research Institue; 2005. 46 p.

18. Skogdirektøren. Recommedations of the Forest director for seed-and plant supply in Norwegian forestry. Land bruks departementet, Oslo, Norway. 1996.

19. Gederaas L, Moen T, Skjelseth S, et al. Ailien species in Norway-the Norwegian blacklist 2012. Artsdatabanken: Trondheim, Norway; 2012.

20. Nyrud AQ. Economy in afforestation-an example from Nordland county. Skogforsk, Norway; 1999. 35-40p.

21. Øyen BH. Revenue from various silvicultural methods in outer coastal sites of western Norway. Norway: Norwegian Forest and Landscape Research Institue; 2012. p. 1-15.

22. Øyen BH. Foreign species in Norway-some experience and result regarding yield. Skogforsk, Norway; 2000. 43-46p.

23. Øyen BH, Tveite BA. Comarison of site index and potential yield between Norway spruce, Scots pine, Downy birch and Sitka spruce on the same site in western Norway. Norway: Norwegian Forest and Landscape Research Institue; 1998. 31p.

24. Andreassen K. Development and yield in selection forest. Norway: Communication Forest Research Institute of West Norway; 1994. 37 p.

25. Øyen BH, Bøhler FA. Comparison of site index and potential yield between Norway spuce and the „noble hardwoods": Beech, Common alder, Sycamore and Oak in south Norway. Norway: Norwegian Forest and Landscape Research Institue; 2011. 22 p.

26. Braastad H. Growth model program for birch. Norway: Norwegian Forest and Landscape Research Institue, Department of Forest Production; 1977. $22 \mathrm{p}$.

27. Bauger E. Volume equations for Scots pine, Norway spruce and Sitka spruce in western Norway. Norway: Norwegian Forest and Landscape Research Institue; 1995. 26 p.

28. Øyen BH, Tveite B. Volume equations and volume tables for tree species in Norway-a review. Skogforsk, Norway; 2002. p. 23-26.

29. Øyen BH, Nygaard PH. Effects of afforstation on growth, yield and local economy. Affornord. Effects on ecosystems, landscape and rural development. In: Halldórsson G, Oddsdottir E, Sigurdsson B, editors. USA: Tema Nord; 2008.

30. Zianis D, Muukkonen P, Mäkipaa R, et al. Biomass and stem volume equations for tree species in Europe. Silva Fennica Monographs. 2005;4:1-63.

31. Smith A, Granhus A, Astrup R, et al. Functions for estimating aboveground biomass for birch in Norway. Scandinavian Journal of Forest Research. 2014;29(6):565-578.

32. Leavy PE, Hale SE, Nicoll BC. Biomass expansion factors and root: shoot ratios for coniferous tree species in Great Britain. Forestry. 2004;77(5):421-430.

33. Marklund LG. Biomass functions for pine, spruce and birch in Sweden. Sweden: Swedish University of Agricultural Sciences; 1988. 73 p. 
34. Repola J. Biomass equations for Scots pine and Norway spruce in Finland. Silva Fenn. 2009;43(4):625-647.

35. Snorrason AE, Einarsson SF. Single tree biomass and stem volume functions for eleven tree species used in Icelandic forestry. Icelandic Agricultural Sciences. 2006;19:15-24.

36. Johnsen PH. Above ground biomass functions of Sitka spruce in Norway Norway: MSc. Thesis, Norwegian University of Environment and Bioscience; 2009.

37. Anon. Biomass measurements in a Sitka spruce stand in Steigen, Nordland county. Norway: Norwegian Forest and Landscape Research Institue; $2011.3 \mathrm{p}$

38. Black K, Tobin B, Saiz G, et al. Improved estimates of biomass expansion factors for Sitka spruce. Irish Forestry. 2004;61:50-65.

39. Tobin B, Nieuwenhuis M. Biomass expansion factors for Sitka spruce (Picea sitchensis (Bong.) Carr.) in Ireland. European Journal of Forest Research. 2007;126(2):189-196.

40. Jenkins JC, Chojnacky DC, Heath LS, et al. National-scale biomass estimators for United States tree species. Forest Science. 2003;49:12-35.

41. Standish JC, Manning GH, Demaerschalk JP. Development of biomass equations for British Colombia tree species. Canada: Pasific Fores Research Centre; 1985. p. 1-49.

42. Smithwick EA, Harmon ME, Remillard SM, et al. Potential uppe bounds of carbon stores in forests of the Pacific Northwest. Ecological Applications. 2002;12:1303-1317.

43. Mason WL, Perks MP. Sitka spruce (Picea sitchensis) forests in Atlantic Europe: Changes in forest management and possible consequences for carbon sequestration. Scandinavian Journal of Forest Research 2012;11:72-81.
44. Poudel BC, Sathre R, Bergh J, et al. Potential effects of intensive forestry on biomass production and total carbon balance in North-Central Sweden. Environmental Science \& Policy. 2012;15(1):106-124.

45. Madsen PN, Nielsen UB. Analyse af mulighederne i nye træarter og artskombinationer samt intensiveret skovbrug. Baggrundsnotat. Skov \& Landskab, Det Natur-og Biovidenskabelige Fakultet, Københavns Universitet, Denmark; 2012. 1-30p.

46. Nielsen UB, Jørgensen BB, Hansen JK. Biomasseproduktion i skoveksempler fra Skov \& landskabs forsøg. Skoven, Denmark; 2011. p. $432-433$.

47. Vadla K. Wood properties of conifers from various sites in NorthernNorway; Density, taper, bark and hartwood. Norway: Skog \& landskap; 2008. p. 1-32.

48. Vadla K. Wood properties of Sitka spruce from various sites in SouthMid- and North-Norway. Norway: Research paper of Skog \& landskap; 2008. p. 1-32.

49. Øyen BH. Estimating aboveground biomass for Norway spruce (Picea abies L. Karst.) in western Norway. Norway: Skog \& landskap, 2012. $13 \mathrm{p}$.

50. Øyen BH. Estimating aboveground biomass in Scots pine trees (Pinus sylvestris L.) in western Norway. Project report Skog og landskap, Norway; 2013. 10 p.

51. Eid T, Brunner A, Søgaard G, et al. Estimation, availability and production of tree biomass resources for energy purposes-a review of research challenges in Norway. INA fagrapport, Norway; 2010.91 p. 